\title{
Palatalization, fortition and deletion in the high vowels of Arcadian Greek
}

\author{
Photini Coutsougera \\ University of Toronto
}

\begin{abstract}
The present study discusses the status of the high vowels /i/ and (secondarily) $/ \mathrm{u} / \mathrm{in}$ Arcadian Peloponnesian, an entirely unstudied variety of Greek. The high vowels of Arcadian Greek undergo different processes or are altogether deleted in an unstressed environment. In particular, unstressed [i] palatalizes or undergoes fortition (depending on the trigger consonant) or gets deleted. Kochetov (2016) argues that palatalization and fortition work in parallel as repair strategies in languages affecting different target consonants, so that marked C+palatal sequences are avoided. This seems to be the motivation behind the widely attested palatalization and fortition in nonstandard Greek varieties more generally, which may need to be unified under one pandialectal study in the future. Until now, high vowel deletion has been thought to be restricted to northern dialects of Greek and has constituted a defining criterion for the classification of Greek dialects in the literature.
\end{abstract}

\section{Peloponnesian Greek: historical background}

The present study focuses on the high vowels and their status in the Modern Greek dialect of Arcadian Peloponnesian, spoken in the area of Arcadia, right in the heart of the Peloponnese peninsula. The phonology of Arcadian Peloponnesian is entirely unstudied. Generally, linguistic studies on the individual Peloponnesian varieties of Greek are few and far between. The prevailing view that Standard Modern Greek (hereafter SMG) is predominantly based on Peloponnesian varieties (amongst others, Newton 1972; Babiniotis 1979, 1998; Kontossopoulos 2001/1994; Browning 1995; Tonnet 1995; Horrocks 2010) seems to have led or at least contributed to the opinion that Peloponnesian varieties are too similar to SMG and therefore not interesting enough to be studied. Newton (1972: 14) aptly remarks on this absence of interest by researchers: "Peloponnesian and Ionian dialects have played a crucial role in the evolution of what Greek scholars now term the 'modern Greek common language', $\eta$

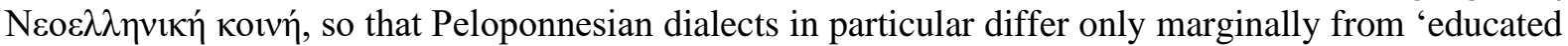
Athenian'. Doubtless because of this, Peloponnesian-Ionian has received disappointingly little attention from Greek scholars and apparently none whatever from foreigners." Over forty years later, Peloponnesian remains sorely under-researched.

This prevailing view regarding the contribution of Peloponnesian dialects (with the exception of Tsakonian and Maniot) to SMG, which has also been oversimplified and rehashed in schoolbooks for decades, has of recent been revisited by scholars. Pantelidis $(2001,2007)$ points out that this view has never been supported by or based on 'specific linguistic data' from Peloponnesian dialects. Essentially, it has been accepted as true without evidence. He then goes on to demonstrate in what ways Peloponnesian and the koine $e^{1}$ precursor of SMG diverge, using data from both. In the same spirit, Mackridge (2014: 134) maintains that "it is much more likely that CMG [Common Modern Greek] ${ }^{2}$ originated in large urban centres where Greeks from various regions had settled, particularly Constantinople, but also ports such as Patra in the Peloponnese, and of course Athens once it became the capital of the Greek kingdom in 1834".

\footnotetext{
${ }^{1}$ A common, non-regional and supra-dialectal variety.

2 Mackridge (2014: 134) defines CMG as "the varieties of Greek that were spoken by people who were trying to avoid regionalisms when conversing with people from other Greek-speaking areas."
} 
A closer look at the literature on the Greek language question or controversy ${ }^{3}$ will allow us to conclude that the linguistic situation in Greece around the time of the foundation of the new State was particularly complex. In fact, scholars never fell short of calling our attention to the complexity of this situation or indeed its idiosyncratic nature due to centuries-long diglossia and, more generally, the complexities that koineisation entails (for a thorough examination, see Mackridge 2009, 2014). For example, Horrocks (2010), who also maintains that the Peloponnesian dialects were the principal popular component of the new koine, also hastens to add that Peloponnesian dialects "were subsumed beneath elite spoken varieties whose impact was reinforced by the aristocratic and middle-class immigrants who flooded into Greece to take up positions of power and responsibility." Additionally, the influence of the prestigious Constantinople dialects (or Constantinople koine by some researchers) and the role of the Ionian (Heptanesian) dialects have been extensively highlighted in the literature.

Although it is my conviction that a systematic study of Peloponnesian would be crucial in determining its role in the then newly forged koine that led to SMG, it is not my intention to take a stance as to the degree of importance that Peloponnesian played in it. However, I would like to contribute to this discussion with a study of Arcadian Peloponnesian which features what has been known until now as one of the most salient features, or rather a defining marker, of northern dialects of Greek, traditionally termed high vowel loss in the literature. As Newton (1972: 16) puts it, high vowel loss and vowel rising "define the limits of the northern dialects".

\section{The dialect of Arcadian Greek}

The data of the present study comes from the mountainous part of the region of Mantineia ${ }^{4}$, situated in the northeastern part of Arcadia, on the slope of Mt Mainalon and bordering on mountainous Gortynia. The study is empirical as the author has a solid passive knowledge of the dialect. As previously mentioned, the phonology of Arcadian Peloponnesian (or, more accurately, Arcadian Peloponnesian varieties) is entirely unstudied. The degree of regional variation within Arcadia remains to be investigated.

\subsection{The current status of Arcadian Greek}

Arcadian Greek (hereafter ArcGr) has been undergoing significant levelling for decades and is still continuously losing ground to SMG. This is certainly true of most other nonstandard varieties of Greek. Arcadian Greek with a fully-fledged phonology, i.e. unaffected by SMG, is still spoken by old people, almost all of whom are bidialectal in ArcGr and SMG. This dialect would have been still fully vibrant at around the end of the 19th century and the beginning of the 20th century and would have been spoken most probably exclusively by monodialectal speakers. Trudgill's (2003) classification and cartographical representation of the Greek dialects also refers to this period, during which, regional dialects were still fully vibrant all over Greece.

According to Pantelidis (2015), the levelling of the Peloponnesian dialects started earlier than in other regions of Greece due to the geographical proximity of the Peloponnese to Athens, the capital of the new State, the increase of language contact between the two through commercial interaction, its advanced infrastructure compared to other regions of Greece etc.

As a result, it seems possible that Peloponnesian varieties have undergone more levelling than other Greek varieties. This would make future research a rather difficult task. After all, the Peloponnese is a large area of Greece with urban centres (chiefly Patras in the north) but also a multitude of towns

\footnotetext{
${ }^{3}$ A dispute around the establishment of an official language (katharevousa vs. demotic) for the Greek State that lasted for well over a century (see Mackridge 1990, 2004, 2009). Katharevousa is a purified artificial form of Greek "based on modern Greek (that is, on the spoken language of educated people and on the written language of the pre-Independence era), but with its orthography, morphology, vocabulary and (to some extent) syntax adjusted, rather unsystematically, so as to conform in part to the rules of ancient Greek grammar." Mackridge (2004: 118).

${ }^{4}$ This municipal unit of Arcadia is generally not particularly mountainous, with the exception of its northeastern part (where the present data stems from) that borders on very mountainous Gortynia.
} 
and villages in its very diverse geographical landscape. However, as long as there still are native speakers around (albeit old and bidialectal) it will not have been left too late.

It should be noted here that the present study is not so much interested in the current phonological situation of levelled ArcGr but rather in what its phonological system looked like prior to any SMG interference.

\subsection{The vowel system of Arcadian Greek}

ArcGr has a basic five-vowel system /i e a o u/, i.e. five monophthongs and no diphthongs. As such, Arcadian Greek and SMG (Mackridge 1985; Joseph and Philippaki-Warburton 1987; Arvaniti 1999; Sfakianaki 2002; Themistocleous 2017) share the same vowel system ${ }^{5}$, possibly with minor acoustic differences. Most Greek varieties share this basic vowel system with SMG (see Trudgill 2009 for exceptions).

\section{The status of high vowels in Arcadian Greek}

SMG and ArcGr differ in that the latter has a plethora of light diphthongs: /i/ semivocalizes and forms a light diphthong with the vowel of the preceding syllable. Semivocalization of $/ \mathrm{i} /$ in this position applies intermorphemically, across morpheme boundaries and across word boundaries. Light diphthongs also feature in SMG but are not common.

The most significant difference in the phonological systems of SMG and ArcGr is the status of their high vowels, /i/ and /u/. In ArcGr, unlike SMG, these appear to be less stable than the other three vowels when unstressed and therefore more vulnerable to their phonological environment.

\subsection{High vowel deletion in Greek}

One can only find short and generic references to the phonology of Peloponnesian in the literature usually in studies of another dialect or dialects - which are not supported by specific data. In particular, unlike in northern dialects, high vowel deletion in Peloponnesian has been described as a fast or casual speech phenomenon: "VD [vowel deletion] is attested in some southern dialects such as SMG and Peloponnesian Greek Dauer 1980; (Baltazani 2006, 2007, a.o.), but to a much lesser degree and typically in "quick casual speech" (Loukina 2008: 323). As a result, it is not considered a feature of the Southern Greek varieties.” (Baltazani, Kainada, Revithiadou, and Topintzi 2016).

Changes in the acoustic quality of vowels, such as devoicing, reduction, etc. are considered common in languages and are naturally attested in SMG and dialects other than the northern ones (see Loukina 2009: 38 for a summary of experimental and non-experimental studies discussing vowel reduction outside of the northern dialects of Greek). A more recent experimental study by Baltazani (2006) has shown that vowel duration in Greek is affected by stress, word length, and the position of the vowel relative to word stress. Thus, vowels have been found to reduce more in longer words and after (rather than before) a stressed syllable. Prior to this, Dauer (1980) had also demonstrated that vowel reduction in SMG predominantly depended on the phonetic environment and the position relative to the stressed syllable.

Nevertheless, fast speech processes are optional and have been claimed to occupy a different place in the phonological component of a language (Kaisse 1985). High vowel deletion in ArcGr, as in northern dialects, is a regular process, central to its phonology.

\footnotetext{
${ }^{5}$ An acoustic study by Fourakis, Botinis, and Katsaiti (1999) shows that the vowels of SMG are maximally dispersed, i.e. arranged closer to the periphery of the vowel space allowing maximal perceptual contrast. Even though possible acoustic differences between the vowels of SMG and ArcGr are not, at least auditorily, readily apparent, it would be worth referring the reader to Trudgill (2009), who looks at Greek dialect vowel systems from the point of view of sociolinguistic typology and argues that it is more likely that the vowel dispersion theory applies to standard varieties of languages rather than nonstandard ones, whose vowels only need to be sufficiently dispersed.
} 


\subsection{The high front vowel /i/}

Stressed [i] maintains its syllabicity in all syllabic positions, within morphemes, across morpheme boundaries and across word boundaries:

(1)

Underlying form
a. /nixta/
b. /peði/
c. /poli meyalo/

Surface form
[níxta]
[peðí]
[poKí meyálo]

\author{
Gloss \\ 'night' \\ 'child' \\ 'very big'
}

Unstressed [i] loses its syllabicity through semivocalization, palatalization or fortition or is deleted. This entirely depends on the preceding and/or following segment in its phonological environment:

1) Post-vocalically (Vi\#, ViC), /i/ semivocalizes and forms a light diphthong with the preceding vowel.

2) Post-consonantally and pre-vocalically $(\mathrm{CiV})$, /i/ either triggers full palatalization in the preceding consonant or undergoes fortition itself.

3) (a) Post-consonantally and word-finally (Ci\#), /i/ triggers either full palatalization in the preceding consonant or is deleted, triggering secondary (or strengthened - see Baltazani et al. 2016) palatalization in the preceding consonant.

(b) When flanked by two consonants (CiC), /i/ either triggers full palatalization in the preceding consonant or is deleted.

We will now look at each case separately:

1) Post-vocalically (ViC, Vi\#), /i/ semivocalizes and forms a light diphthong with the vowel of the preceding syllable, thus resolving the undesired hiatus.

Each example below is chosen to include /i/ following each one of the five vowels of ArcGr, with which it forms a light diphthong. In SMG, the words below (i.e. the shared ones: $2 b, 2 d, 2 e$ ) would have one extra syllable:

(2) Post-vocalic/i/ across morpheme boundaries:

$\begin{array}{lll}\text { Underlying form } & \text { Surface form } & \text { Gloss } \\ \text { a. /pi-i/ } & \text { [píj] } & \text { 'who.PL' } \\ \text { b. /le-i/ } & {[\text { léj] }} & \text { 'say.3sG' } \\ \text { c. /e-ka-i/ } & \text { [ekáj] } & \text { 'burnt.PAST.3sG' } \\ \text { d. /rolo-i/ } & \text { [rolój] } & \text { 'clock/watch' } \\ \text { e. /xu-i/ } & \text { [xúj] } & \text { 'habit' }\end{array}$

(3) Post-vocalic /i/ intermorphemically:

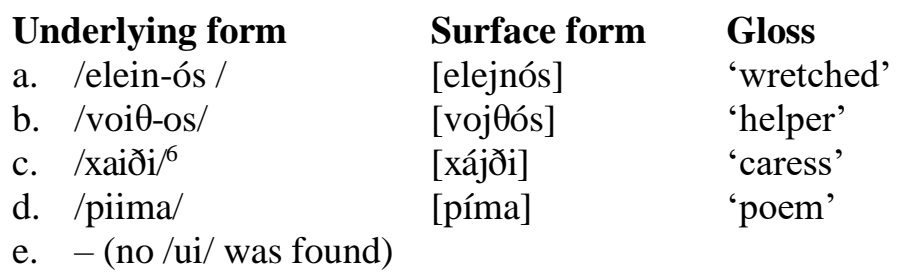

\footnotetext{
${ }^{6}$ [xájði] < medieval [ixáði], 'little sound’ with metathesis.
} 
(4) Post-vocalic /i/ across word boundaries:

$\begin{array}{lll}\text { Underlying form } & \text { Surface form } & \text { Gloss } \\ \text { a. /me iðe/ } & \text { [méjðe] } & \text { 's/he saw me' } \\ \text { b. /ta ifera/ } & \text { [tájfera] } & \text { 'I brought them' } \\ \text { c. /to ipa/ } & \text { [tójpa] } & \text { 'I said it' } \\ \text { d. /pu ise/ } & \text { [pújse] } & \text { 'Where are you?' } \\ \text { e. /ti ipes/ } & \text { [típes] } & \text { 'What did you say?' }\end{array}$

As can be seen, adjacency of two high front vowels as in (3d) and (4e) will result in the deletion of the first of the two, rather than semivocalization of the second. It should be noted that these sequences are quite rare in the first place. Also, [ij] (as in 2a) is only attested in word-final position in masculine plural nouns, adjectives and pronouns ending in -ios. Therefore, hiatus is resolved with deletion in (3) and (4) and semivocalization in (2).

f):

Hiatus is resolved with the help of an epenthetic $j$ across i\# \#V (5a-d) or iV word-medially (5e-

$\begin{array}{lll}\text { Underlying form } & \text { Surface form } & \text { Gloss } \\ \text { a. /i ali/ } & {[\mathrm{i} \text { já }]} & \text { 'the other.FEM.' } \\ \text { b. /i eleni/ } & {[\mathrm{i} \text { jelén] }} & \text { '(the) Helen' } \\ \text { c. /i jaspri fusta/ } & {[\mathrm{i} \text { jáspri fústa] }} & \text { 'the white skirt' } \\ \text { d. /i omorfes/ or /i emorfes/ } & {[\mathrm{i} \text { jómorfes] or [i 'jémorfes] }} & \text { 'the pretty ones.FEM.' } \\ \text { e. /krieno/ } & \text { [krijéno] } & \text { 'to be cold' } \\ \text { f. /peripieme/ } & \text { [perpijéme] } & \text { 'to look after' }\end{array}$

It should finally be noted that there is a number of ArcGr words featuring light diphthongs that do not come from an underlying /i/ source. A small sample of them is provided in (6) below ${ }^{7}$.

(6)
ArcGr
SMG
Gloss
a. [klájma]
[kláma] 'crying'
b. [kájӨe]
[ká日e] 'each'
c. [lejmón]
[lemóni]
'lemon'
d. [rojðinízo]
'to ripen, to have rosy cheeks'

2) In $\mathrm{CiV}$ context, /i/ either triggers full palatalization in the preceding dorsal ( $\mathrm{k}, \mathrm{x}, \mathrm{\gamma})$ and alveolar coronal (except $\mathrm{r}$ ) or otherwise undergoes fortition itself (i.e. after labials, dental coronals and r). $\mathrm{CiV}$ sequences are all heteromorphemic in (7) and (8) and tautomorphemic in (9).

The underlying singular forms, where stressed syllabic [i] appears, are provided simply to justify the existence of an underlying /i/ in the plural forms. There are also other morphophonological alternations that justify this.

\footnotetext{
${ }^{7}$ Some of them are medieval and can be found in the medieval dictionary of Kriaras (1969-2016).
} 
(7) Full palatalization:

Underlying form Surface form Gloss $\quad$ Surface form

Plural forms of neuter nouns ending in $-i$

Singular forms

\begin{tabular}{|c|c|}
\hline a. /sak-ia/ & [satc $\left.{ }^{8} a ́\right]$ \\
\hline b. /pug-ia/ & [pujáa \\
\hline c. /tzox-ia/ & [tzoçáa \\
\hline d. /tray-ia/ & [trajá] \\
\hline e. /nis-ia/ & [nifá] \\
\hline f. /yaz-ia/ & [yazá] \\
\hline g. /pan-ia/ & [paná] \\
\hline h. /ðavl-ia/ & [ðavKá] \\
\hline
\end{tabular}

$\begin{array}{ll}\text { 'sacs' } & \text { [satc-í] } \\ \text { 'pouches' } & \text { [puj-1́] } \\ \text { 'kind of herb' } & \text { [tzoç-1́] } \\ \text { 'male goats' } & \text { [traj-í] } \\ \text { 'islands' } & \text { [nif-í] } \\ \text { 'stitches' } & \text { [yaz-1́] } \\ \text { 'cloths' } & \text { [pan-1́] } \\ \text { 'torches' } & \text { [ðav } \Lambda \text {-1́] }\end{array}$

(8) Fortition:

\begin{tabular}{|c|c|c|c|}
\hline Underlying form & Surface form & Gloss & Surface form \\
\hline \multicolumn{3}{|c|}{ Plural forms of neuter nouns ending in $-i$} & Singular forms \\
\hline /pap-ia/ & [papçá] & 'ducks' & [pap-1́] \\
\hline /aft-ia/ & [aftçá] & 'ears' & [aft-1́] \\
\hline /karf-ia/ & [karfçá] & 'nails' & [karf-1́] \\
\hline /spa $\theta-\mathrm{ia} /$ & [spaقçá] & 'swords' & 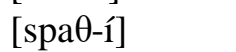 \\
\hline /kub-ia / & [kubjá] & 'buttons' & [kub-í] \\
\hline /yiurd-ia / & [jurdjáa & $\begin{array}{l}\text { 'traditional } \\
\text { women's coats' }\end{array}$ & [jurd-1́] \\
\hline /kluv-ia/ & [kluvjá] & 'cages' & [kluv-1́] \\
\hline /peð-ia/ & [peðjá] & 'children' & [реð-1́] \\
\hline /tir-ia/ & [tirjá] & 'cheeses' & [tir-1́ \\
\hline /psom-ia/ & [psomjá] & 'breads' & [psom-1] \\
\hline
\end{tabular}

Heteromorphemic $\mathrm{CiV}$ sequences identical to the ones in (7) and (8) abound in feminine nouns ending in -ia (e.g. /evyen-ia/ > [evjéna], 'politeness', /prospa $\theta-i a /$ > [prospá $\theta$ ça], 'attempt, try' etc.), adjectives ending in -ios, -ia, -io (e.g. /yamíl-ios/ > [yamíios], 'matrimonial - nom./acc.', /ip-ios/ > [ípços], 'mild'- nom./acc. sg. etc.) or neuter nouns ending in -io (e.g. / $/$ emel-io/ >

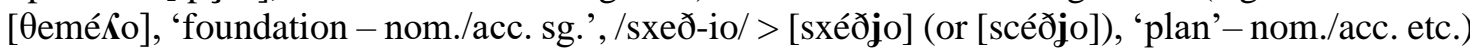
as well as in i-ending prefixes attached to a vowel-initial stem.

Tautomorphemic CiV sequences are not as frequent (e.g. /piat-o/ [pçáto], 'plate' etc.) and are mostly found within the common and quite productive prefix /ðia/ > [ðja], 'through, trans-' when this is attached to a consonant-initial stem $(9 \mathrm{a}-\mathrm{c})$. This prefix drops its final vowel when attached to a vowel-initial stem (9d-f). Some examples with i-ending prefixes attached to a vowel-initial stem are also provided in $(9 \mathrm{~g}-\mathrm{j})$ below.

\footnotetext{
${ }^{8}$ In ArcGr, dorsals and non-rhotic alveolar coronals are palatalized before the front vowels [i] and [e]. The underlying velar $/ \mathrm{k} /$ is fronted into what sounds more like an alveolo-palatal sound before front vowels rather than a palato-alveolar one. It is produced with considerable raising of the front of the tongue (a tongue-body shape for alveolo-palatals) and has little lip rounding. Hence the choice of the symbol $/ \mathrm{t} 6 /$, following Manolessou and Pantelidis (2013).
} 
(9)

\begin{tabular}{|c|c|c|}
\hline Underlying form & Surface form & Gloss \\
\hline a. /ðia+ yoyi/ & [ðјауојí] & 'conduct' \\
\hline b. /ðia+yrama/ & [ðjáyrama] & 'diagram, chart' \\
\hline c. /ðia+ðoxos/ & [ðjáðoxos] & 'heir' \\
\hline d. /ði+arkia/ & [ðjárca] & 'duration' \\
\hline e. /ði+e日nis/ & [ðje日nís] & 'international' \\
\hline f. /ði+orӨoma/ & [ðjórӨoma] & 'correction' \\
\hline g. /epi+usios/ & [epjúfos] & 'daily bread' \\
\hline h. /peri+usia/ & [perjufía] & 'property' \\
\hline i. /imi+aryia/ & [imjarjía] & 'semi-holiday' \\
\hline j. /anti+evropaikos/ & [adjevropajkós] & 'anti-European' \\
\hline
\end{tabular}

A similar picture to that in (7) and (8) applies to SMG (with the exception of /k/, as in [sacá], and the sibilants that trigger /i/ fortition, as in [nisja], [yazja]). However, in SMG, unstressed [i] does not always palatalize in the environment of (7) and does not always undergo fortition in the environment of (8) and (9). Its behaviour is not at all uniform in the above environments. Katharevousa rules, which demand that [i] stays syllabic as much as possible, frequently interfere with the application of palatalization and fortition. For example, despite the fact that [paná] </pan$\mathrm{ia} /$ and [evjénia] < /evyen-ia/ share the same $/ \mathrm{CiV} /$ environment, the former features palatalization while the latter features a syllabic [i] in SMG. In examples (10g-i) below, two outputs are possible in SMG, with the second being more likely to appear in more formal registers of speech (e.g. the news broadcast). There are hundreds of examples that fit this description in SMG. Compare the two varieties:

\begin{tabular}{|c|c|}
\hline Underlying form & SMG \\
\hline a. /evyen-ia/ & [evjénia] \\
\hline b. /prospa $\theta-\mathrm{ia} /$ & [prospá $\theta \mathbf{i a}]$ \\
\hline c. /ip-ios/ & [ípios] \\
\hline d. /yamil-ios/ & [yamílios] \\
\hline e. /Oemel-io/ & [Өemélio] \\
\hline f. /sxeð-io/ & [sxéðio] \\
\hline g. /ðia+ уоуi/ & [ðјауојí] or [ðiayojí] \\
\hline h. /ðia+yrama/ & [ðjáyrama] or [ðiáyrama] \\
\hline i. /ðia+ðoxos/ & [ðjáðoxos] or [ðiáðoxos] \\
\hline j. /ði+arkia/ & [ðiárcia] \\
\hline k. /ði+e日nis/ & [ðieOnís] \\
\hline 1. /ði+orӨoma/ & [ðiórӨoma] \\
\hline m. /epi+usios/ & [epiúfos] \\
\hline n. /peri+usia/ & [periufía] \\
\hline o. /imi+aryia/ & [imiarjía] \\
\hline p. /anti+evropaikos/ & [a(n)dievropaikós] \\
\hline
\end{tabular}

\begin{tabular}{|c|c|}
\hline ArcGr & Gloss \\
\hline [evjéna] & 'politeness' \\
\hline [prospá $\theta$ ça] & 'attempt, try' \\
\hline [ípços] & 'mild' \\
\hline [yamíKos] & 'matrimonial' \\
\hline [Өeméкоo] & 'foundation' \\
\hline [sx/céðjo] & 'plan' \\
\hline [ðјауојі́] & 'conduct' \\
\hline [ðjáyrama] & 'diagram, chart' \\
\hline [ðjáđoxos] & 'heir' \\
\hline [ðjárca] & 'duration' \\
\hline [ðjeӨjís] & 'international' \\
\hline [ðjór $\theta$ oma] & 'correction' \\
\hline [epjúfos] & 'daily bread' \\
\hline [perjufía] & 'property' \\
\hline [imjarjía] & 'semi-holiday' \\
\hline [adjevropajkós] & 'anti-European' \\
\hline
\end{tabular}

3) (a) In Ci\# context /i/ triggers either full palatalization in the preceding consonant or drops, triggering at the same time secondary (or strengthened - see Baltazani et al. 2016) palatalization in the preceding consonant. This word-final context is the most vulnerable for vowel loss. 
(11)

Underlying form Surface form Gloss

Proper names in nominative (only for fem.) / accusative / vocative
a. /mak-i/
[mác]
'Makis', short for 'Michael'
b. $/ \mathrm{max}-\mathrm{i} /$ [máç]
c. /yeory-i/ [jóri]
d. /ðionis-i/ [ðjoníf]
e. /roz-i/ [róz]
f. /adon-i/ [adón]
'Machi', short for 'Andromache'
'George'
'Dionysius'
g. /vasil-i/
[vaJík]
'Antony'
'Vasilis'

(12)

\section{Underlying form Surface form Gloss}

Proper names in nominative (only for fem.) / accusative / vocative
a. /pop-i/
[póp $\left.{ }^{\mathbf{j}}\right]$
b. /bab-i/
[báb $\left.{ }^{\mathrm{j}}\right]$
c. /fot-i/
[fót t $\left.^{\mathrm{j}}\right]$
d. /valad-i/
[valád $\left.\mathbf{d}^{\mathrm{j}}\right]$
e. /sif-i/
[Sifi $]$
f. $/$ sta $\theta-\mathrm{i} /$
[stá $\theta^{j}$ ]
g. /fiv-i/
[fívi $\left.{ }^{j}\right]$
h. /aristið-i/
[arstí $\left.\mathbf{o}^{\mathbf{j}}\right]$
i. /sotir-i/
[sotírír]
j. $/ \mathrm{mim}-\mathrm{i} /$
[mím $\left.{ }^{\mathrm{j}}\right]$
'Popi', short for 'Penelope'
'Babis', short for 'Charalambos'
'Photius'
'Valantis'
'Sifis'
'Stathis'
'Phoebe'
'Aristides'
'Sotiris'
'Mimis', short for 'Demetrius'

The following examples from Baltazani et al. (2016: 7) belong to Kozani Greek, a northern variety, but could well be ArcGr (13j is debatable):

(13)
a. /ðjavas-i/
[ðja'vaf]
'read.3SG'
b. /luz-i/
[luz]
c. /elen-i/
[e'lep]
'wash.3sG'
d. /pol-i/
e. /skin-ak-i/
[poК]
'Helen'
f. /anem-i/
[Sci'nac]
'city'
g. /ðond-i/
[a'nem ${ }^{+}$]
'rope, diminutive'
$\begin{array}{ll}\text { h. } & \text { /vrað-i/ } \\ \text { i. } / \text { spit-i/ }\end{array}$
[ðond ${ }^{+}$]
'spinning wheel'
[vrað $\left.{ }^{+}\right]$
'tooth'
'evening'
$\left[\mathrm{pit}^{+}\right]$
j. /kunav-i/
$\left[\mathrm{knav}^{+}\right]$
'house, home'
k. /xasap-i-s/
[xa' sap $^{+}$s]
'ferret'
'butcher'

Baltazani et al. (2016) propose that high vowel deletion in this context triggers strengthened palatalization (and not secondary palatalization) in the preceding consonant in Kozani Greek. This extension to the current palatalization typology (see Kochetov 2016) is said to be justified on both phonetic and phonological grounds: "The need for this addition is justified on both phonetic and phonological grounds; its acoustic output is dissimilar to both full and secondary PAL [palatalization], while the triggering force is not the presence of a front vocoid but rather the loss of 
it in unstressed positions." (Baltazani et al. 2016: 5). Therefore, they take secondary and strengthened palatalization to be two distinct processes: in the former, the high front vocoid is present in the output as a secondary gesture, while in the latter it is not. Additionally, they found that no F2 raising was detected in the vowel of the relevant $\mathrm{VC}$ sequences in the surface forms of (13), while frication, aspiration and lengthening were detected instead.

In ArcGr, the final consonants in (12) are auditorily distinct from corresponding ones in SMG that have not undergone secondary (or strengthened) palatalization. The loss of the nuclear vowel becomes particularly clear, even for the untrained ear, when the names above are called out, i.e. when used in vocative case. Here they carry the notation of secondary palatalization, although an acoustic analysis would determine the kind of palatalization that these consonants undergo more accurately.

Palatalization and deletion in (11) and (12) give rise to a number of marked consonant clusters and prosodic structures which are not found in SMG and which differentiate the two systems quite dramatically. Topintzi and Baltazani (2012: 2) found that corresponding clusters in Kozani Greek were "less stable in duration than underlying ones".

3) (b) In $\mathrm{CiC}$ context /i/ either triggers full palatalization in the preceding consonant or is deleted. The examples below were chosen to contain a post-tonic /i/:

\section{Underlying form Surface form Gloss}

\section{Palatalization}

\begin{tabular}{|c|c|c|}
\hline a. /filip-as/ & [fínpas] & 'Philip' \\
\hline b. /paralit-o/ & [paránto] & 'paralyzed (lit.), crazy (fig.)' \\
\hline c. /aftokinit-o/ & [aftocínto] & 'car' \\
\hline d. /kokin-o/ & [kóteno] & 'red' \\
\hline e. /xasim-o/ & [xáfmo] & 'loss' \\
\hline f. /e-zis-e/ & [ézse] & 'lived.3SG’ \\
\hline g. /e-paxin-e/ & [epáçne] & 'gained weight.3sG' \\
\hline h. /e-yin-e/ & [éjne] & ‘happened.3SG’ \\
\hline
\end{tabular}

\section{Deletion}

\begin{tabular}{|c|c|c|}
\hline i. /e-pis-e/ & [épse] & 'convinced.3SG' \\
\hline j. /e-zitis-e/ & [ezítse] & 'asked.3SG' \\
\hline k. /afik-e/ & [áfce] & 'left, let.3sG' \\
\hline 1. /e-viks-e/ & [évkse] & 'coughed.3SG' \\
\hline m. /e-me日is-e/ & [emé $\theta$ se] & 'got drunk.3SG' \\
\hline n. /e-ðis-e/ & [éðse] & 'set, sunk.3sG' \\
\hline
\end{tabular}

The examples under palatalization (14a-h) have one syllable less than their corresponding SMG counterparts after the loss of the nuclear vowel in the relevant syllables. The examples under deletion (14i-n) also sound reduced by one syllable compared to their SMG counterparts but whether there is still any phonetic evidence of a vowel in the relevant syllable needs to be established with an acoustic analysis. The term deletion is therefore used to cover [i] devoicing, reduction (in duration and/or quality) or elision for (14i-n). An acoustic analysis of the above data at a later stage would determine their exact status.

Finally, it would also be interesting to note here that in some loanwords $[K]$ is treated as an underlying /li/: 
(15)

$\begin{array}{lll}\text { ArcGr } & \text { SMG } & \text { Gloss } \\ \text { [zvéitos] } & \text { [zvéltos] } & \text { 'svelte' } \\ \text { [vóíta] } & \text { [vólta] } & \text { 'stroll' } \\ \text { [paরitó] } & \text { [paltó] } & \text { 'coat' }\end{array}$

\subsection{The high back vowel /u/}

Before we discuss /u/, we must bear in mind that it is much less frequent than /i/ and by far the least frequent of all five vowels of Greek (Protopapas, Tzakosta, Chalamandaris, and Tsiakoulis 2012). In that sense, we are presented with a small challenge, as not all possible phonetic contexts are amenable to examination.

To begin with, stressed $[\mathrm{u}]$ retains its syllabicity intermorphemically and across morpheme boundaries (e.g. /surn-o/ > [súrno] 'drag', /lem-u/ > [lemú] 'neck - gen.' etc.). As with unstressed [i], unstressed $[\mathrm{u}]$ is susceptible to its environment. As already mentioned, we will have to bypass certain contexts: $\mathrm{VuC}, \mathrm{Vu} \#$ and $\mathrm{CuV}$. The first two are rare and can mainly be found in the genitive case of a handful of masculine nouns and adjectives, some of which are not even dialectal. At the same time, $\mathrm{CuV}$ context is extremely rare and can be found in very few non-dialectal loanwords.

We are therefore left with $\mathrm{Cu} \#$ and $\mathrm{CuC}$. Word-finally $(\mathrm{Cu})$, unstressed $[\mathrm{u}]$ can be found in the genitive case of masculine and neuter nouns and adjectives ending in -os and -o respectively (16). It can also be found at the end of some adverbs (17). In this vulnerable word-final position, [u] is deleted and there is a reduction in syllable number by one in the relevant words.

Impressionistically, the final consonants (in bold type) in the second column in (16) are produced differently from their counterparts in SMG. An acoustic analysis would confirm whether labialization as a secondary articulatory gesture is in place.

\begin{tabular}{|c|c|c|}
\hline $\begin{array}{l}\text { Underlying form } \\
\text { a. /topu// }\end{array}$ & $\begin{array}{l}\text { Surface form } \\
{\left[\text { tóp } \mathbf{p}^{\mathrm{w}}\right]}\end{array}$ & $\begin{array}{l}\text { Gloss } \\
\text { 'place' }\end{array}$ \\
\hline b. /yatu/ & [yát $\left.{ }^{\mathrm{w}}\right]$ & 'male cat' \\
\hline c. /laku/ & [lák $\left.\mathbf{k}^{\mathrm{w}}\right]$ & 'loom’' \\
\hline d. /kabu/ & {$\left[\mathrm{ká} \mathbf{b}^{\mathrm{w}}\right]$} & ‘plain’' \\
\hline e. /podu/ & [pód ${ }^{\mathrm{w}}$ ] & 'centimetre' \\
\hline f. /pagu/ & [pág $\left.{ }^{\mathrm{w}}\right]$ & 'bench' \\
\hline g. /psifu/ & {$\left[\mathrm{p} \int \mathbf{i}^{\mathrm{w}}{ }^{\mathrm{w}}\right]$} & 'vote' \\
\hline h. /sklavu/ & [skláv ${ }^{\mathrm{w}}$ ] & ‘slave’' \\
\hline i. /mara $\theta u /$ & {$\left[\right.$ mára $\left.\theta^{\mathrm{w}}\right]$} & 'fennel' \\
\hline j. /kuniaðu/ & [kunádw] & 'brother-in-law' \\
\hline k. /asu/ & [ás $\left.{ }^{\mathrm{w}}\right]$ & 'ace’ \\
\hline 1. /rozu/ & {$\left[\right.$ róz $\left.\mathbf{z}^{\mathrm{w}}\right]$} & 'lump, callous' \\
\hline m. /vraxu/ & [vrá $\mathbf{x}^{\mathrm{w}}$ ] & 'rock' \\
\hline n. /payu/ & [páy $\left.{ }^{\mathrm{w}}\right]$ & ‘ice’' \\
\hline o. /yamu/ & [yámw] & 'wedding' \\
\hline p. /tonu/ & [tón $\left.{ }^{w}\right]$ & ‘ton’ \\
\hline q. /filu/ & {$\left[\mathrm{f} \mathbf{1} \mathbf{w}^{\mathrm{w}}\right]$} & 'friend' \\
\hline r. /yeru/ & [jér $\left.\mathbf{r}^{\mathrm{w}}\right]$ & 'old man' \\
\hline
\end{tabular}


(17)

\begin{tabular}{|c|c|c|}
\hline Underlying form & Surface form & Gloss \\
\hline a. /apanu/ & [apánw] & 'on top' \\
\hline b. /katu/ & {$\left[\mathrm{ká}^{\mathrm{w}}{ }^{\mathrm{N}}\right]$} & 'down' \\
\hline c. /xamu/ & [xámw] & 'on the ground' \\
\hline d. /kaӨolu/ & [kaقól $\left.{ }^{w}\right]$ & 'not at all' \\
\hline e. /kapu/ & [kápw] & 'somewhere' \\
\hline
\end{tabular}

Some of the above are reduplicated for emphasis (e.g. [apán ${ }^{\mathrm{w}}$ apán $\left.{ }^{\mathrm{w}}\right]$ ) or to form a different meaning (e.g. [káp $\left.{ }^{w}\right]\left[k a ́ p{ }^{w}\right]$, 'now and then').

When unstressed $[\mathrm{u}]$ is flanked by two consonants it is deleted. As with [i] in the same position, the term deletion is used to cover devoicing, reduction (in duration and/or quality) or elision. Also, we need to establish whether pre-tonic $[\mathrm{u}]$ is affected differently from post-tonic $[\mathrm{u}]$ with more examples. An acoustic analysis of the data would determine their status with accuracy.
Underlying form
a. /kotopulo/
b. /mayulo/
c. /kurvulo/
d. /alupu/
e. /yurunopula/

Surface form
[kotóplo]
[máylo]
[kúrvlo]
[alpú]
[yurnopúla]

Gloss
'chicken'
'cheek'
'vine root'
'fox'
'pork roast'

Once again, deletion gives rise to a number of consonant clusters and prosodic structures, which make ArcGr diverge from SMG significantly.

Across word boundaries, $[u]$ is deleted before $[a]$ and $[o](19 a-b)$, triggers semivocalization in the following /i/ (19c) and coalesces with a following [e] (19d-f):
Underlying form
a. /mu afike/
b. /pu ormineva/
c. /su ipe/
d. /mu eðoke/
e. /mu ekame/
f. /pu epa $\theta \mathrm{a} /$

Surface form
[máfce]
[pormíneva]
[sújpe]
[módoce]
[mókame]
[pópa $\theta$ a]

\author{
Gloss \\ '(s/he) left (for) me' \\ 'that I was advising' \\ '(s/he) told you' \\ '(s/he) gave me' \\ '( $\mathrm{s} / \mathrm{he}$ ) did to me' \\ 'that (I) suffered'
}

The status of the high back vowel /u/ has occupied a shorter space in this study and needs to be further investigated in the future.

\section{Discussion}

The behaviour of high vowels, and /i/ in particular, in ArcGr is interesting for various reasons. Firstly, it bears striking similarities to other nonstandard Greek dialects, which, to the best of my knowledge, do not retain a syllabic [i] in an unstressed position, at least in CiV context (see Newton 1972 for the most comprehensive theoretical work on Modern Greek dialects). Secondly, it improves our understanding of the mechanisms that these vowels deploy in a vulnerable unstressed context.

It would be simply inadequate to put deletion down to the fact that /i/ and /u/ are the shortest unstressed vowels in Greek (Fourakis et al. 1999; Dauer 1980). Viewing their behaviour in ArcGr through the prism of the theory of markedness would help us understand it in more depth. To begin with, the fact that /i/ is unable to retain its syllabicity in an unstressed position can easily be explained 
through markedness, as $\mathrm{C}+$ palatal sequences $(\mathrm{C}+$ consonant, $\mathrm{C}+$ glide and $\mathrm{C}+$ vowel) are considered marked cross-linguistically (see Kochetov 2016). According to Kochetov (2016), the phonetic motivation for this lies in the fact that the palatal gesture always conflicts with other lingual gestures produced further front or further back in the oral cavity. Additionally, these sequences are acoustically and perceptually problematic.

In that respect, SMG is significantly more marked than ArcGr as it often favours a highly marked syllabic /i/ in unstressed positions, even in the very susceptible post-consonantal pre-vocalic environment $(\mathrm{CiV})$. This is hardly surprising if we take into consideration the fact that SMG evolved less than naturally and was heavily affected by cumbersome katharevousa rules.

Kochetov (2016), using data from Kirundi and, amongst other languages, the Greek dialect of Kos (strikingly similar to ArcGr /i/ data), argues for a 'functional and formal affinity' between palatalization and fortition as repair strategies in languages, proposing that they work in parallel, affecting different target consonants with the ultimate goal that marked $\mathrm{C}+\mathrm{j}$ sequences are avoided. Kochetov (2016) therefore argues that unless we unify these two seemingly unrelated phenomena, we may miss important generalizations in the behaviour of $\mathrm{C}+\mathrm{j}$ sequences.

Furthermore, vowel deletion should not be seen separately from palatalization and glide fortition either as it also seems to be strongly related to them. In other words, /i/ first takes recourse to palatalization or fortition that ensure that it will 'survive' (or at least some of its features) through the coalesced palatal output or, even better, through the strengthened output of fortition. As shown here, in ArcGr, full palatalization is triggered after dorsals and alveolar coronals, while fortition is triggered after labials and dental coronals. Deletion, which is also one of the strategies deployed to avoid $\mathrm{C}+\mathrm{j}$ sequences (along with palatalization, fortition, epenthesis and metathesis - see Kochetov 2016), always seems to be the last resort.

Finally, it is possible that unstressed [i] changes into [e] in order to survive and not perish:

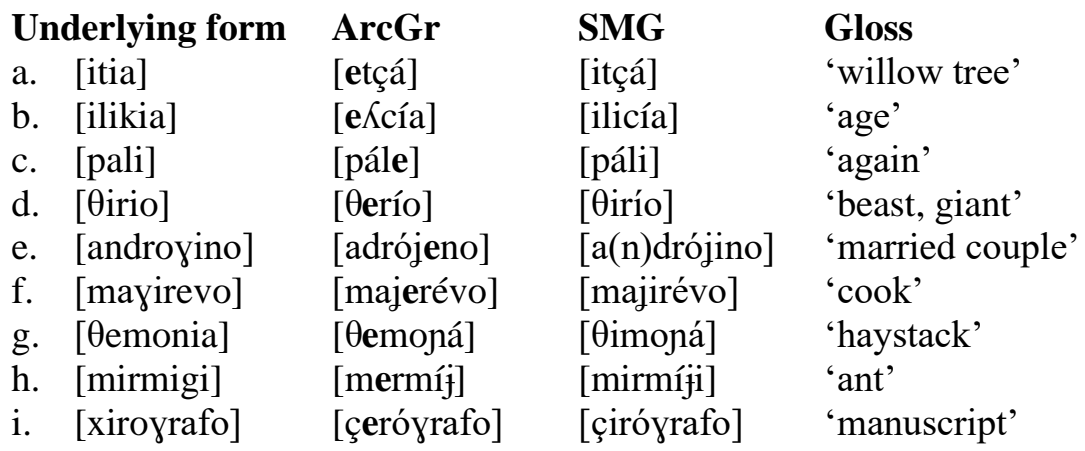

Some of the examples above also appear in nonstandard dialects other than ArcGr.

To sum up, translated into optimality theory terminology, the proposed contextual markedness *C+palatal constraint proposed by Kochetov (2016) seems to be the motivation behind glide palatalization and fortition in nonstandard Greek varieties, which we may need to unify under one pandialectal study in the future (see also Baltazani and Topintzi 2012).

\section{Sociolinguistic implications}

High vowel loss, as it is traditionally termed, is perhaps the most basic or defining criterion used throughout the history of Greek dialectology for the classification of Greek dialects (amongst others, Hatzidakis 1905; Triandaphyllidis 1938; Tzitzilis 2001; Argiriadis 1990; Newton 1972). For example, Hatzidakis (1892) was the first one to use high vowel loss as the diagnostic criterion for the 
classification of Greek dialects, and his division of them into northern and southern is based solely on it.

Trudgill (2003) also deploys high vowel loss as one of his criteria for the classification and first ever cartographical representation of the Greek dialects, a notoriously difficult task for various linguistic and non-linguistic reasons. He proposes fifteen areas on the dialectal map of Greek. On that map, Peloponnesian is classified along with the Heptanese and North Epirus with the Central group of Greek dialects: "Western Epirus, Corfu, Kephalonia, Zakinthos, the Peloponnese. This area corresponds more or less to Newton's Peloponnesian-Ionian area and has none of the six features we have been employing as criteria. This is not surprising in view of the fact that the Ionian islands and the Peloponnese are generally agreed to have supplied most of the input into Standard Greek (Horrocks 1997: 300), although this has been disputed, at least for the Peloponnese, by Pantelidis (2001b)." (Trudgill 2003: 58-59).

However, as shown in the present study, high vowel loss (a) also features in Peloponnesian Greek, and (b) should be viewed in conjunction with palatalization and glide fortition (in relation to /i/). The sociolinguistic implications of this study could be significant. If high vowel loss is found anywhere from northern to southern dialects of Greece it fails to do its job. One way around this problem would be to abandon high vowel loss as a criterion for the classification of the Greek dialects and use mid vowel raising instead, which is restricted to northern dialects alone.

Acknowledgements. I would like to thank the members of the phonology reading group of the University of Toronto and the audience of MOT Phonology/Phonetics Workshop 2019 for their useful comments. Finally, I owe special thanks to Professor Peter Mackridge for valuable discussions on the Greek language question.

\section{References}

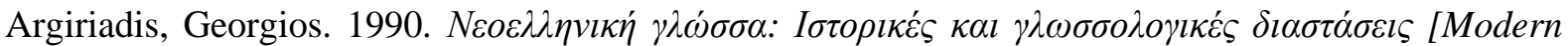
Greek: Historical and linguistic dimensions]. Thessaloniki: Kyriakidis.

Arvaniti, Amalia. 1999. Illustrations of the IPA: Standard Modern Greek. Journal of the International Phonetic Association 29(02): 167-172.

Babiniotis, Georgios. 1979. A linguistic approach to the language question in Greece. Byzantine and Modern Greek Studies: 1-16. Oxford: Basil Blackwell.

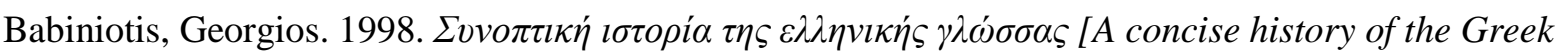
language]. Athens: Ellinika Grammata.

Baltazani, Mary. 2006. Focusing, prosodic phrasing, and hiatus resolution in Greek. In Laboratory phonology, eds Louis Goldstein, Douglas H. Whalen and Catherine T. Best, 473-494. Berlin: Mouton de Gruyter.

Baltazani, Mary. 2007. Prosodic rhythm and the status of vowel reduction in Greek. In Selected Papers on Theoretical and Applied Linguistics from the 17th International Symposium on Theoretical and Applied Linguistics, eds Eleni Agathopoulou, Maria Dimitrakopoulou, and Despoina Papadopoulou, 31-43. Thessaloniki: Department of Theoretical and Applied Linguistics.

Baltazani, Mary, and Nina Topintzi. 2012. On some phonetic and phonological properties of the Greek glide. In Selected Papers of the 10th International Conference of Greek Linguistics, eds Zoe Gavriilidou, Angeliki Efthymiou, Evangelia Thomadaki, and Penelope KambakisVougiouklis, 153-166. Komotini: Democritus University of Thrace.

Baltazani, Mary, Evia, Kainada, Anthi, Revithiadou, and Nina Topintzi. 2016. Vocoid-driven processes: Palatalisation and glide hardening in Greek and its dialects. Glossa: a journal of general linguistics, 1(1) 23: 1-28. 
Browning, Robert. 1995. Medieval and Modern Greek. Second Edition. Cambridge: Cambridge University Press.

Dauer, Rebecca. 1980. The reduction of unstressed high vowels in modern Greek. Journal of the International Phonetic Association 10: 17-27.

Fourakis, Marios, Antonis Botinis, and Maria Katsaiti. 1999. Acoustic characteristics of Greek vowels. Phonetica 56: 28-43.

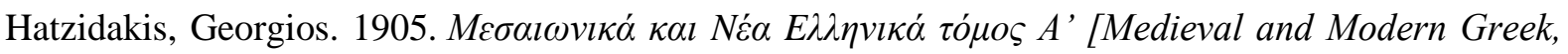
Vol. A]. Athens: Vivliothiki Marasli, Typois P. D. Sakellariou Publications.

Horrocks, Geoffrey. 2010. Greek: A history of the language and its speakers. Second Edition. Chichester.

Joseph, Brian, and Irene Philippaki-Warburton. 1987. Modern Greek. London: Croom Helm.

Kaisse, Ellen. 1985. Connected speech: the interaction of syntax and phonology. New York: Academic Press.

Kochetov, Alexei. 2016. Palatalization and glide strengthening as competing repair strategies: Evidence from Kirundi. Glossa: a journal of general linguistics 1(1) 14: 1-31.

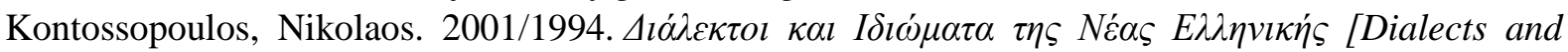
varieties of Modern Greek]. Athens: Gregoris Publications.

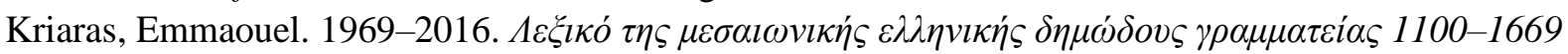
[Lexicon of Medieval Greek Demotic Literature 1100-1669], 20 vols. Thessaloniki.

Loukina, Anastassia. 2008. Acoustic model of stress in Standard Greek and Greek dialects. In Proceedings of ISCA tutorial and research workshop on experimental linguistics, ed. Antonis Botinis, 149-152. Athens: University of Athens.

Loukina, Anastassia. 2009. Phonetic variation in spontaneous speech: Vowel and consonant reduction in Modern Greek dialects. In Oxford University Working Papers in Phonetics volume 12 eds Elinor Payne, and Ōiwi Parker-Jones, 36-56. University of Oxford.

Mackridge, Peter. 1985. The Modern Greek Language. Oxford: Oxford University Press.

Mackridge, Peter. 1990. Katharevousa (c. 1800-1974). An obituary for an official language. In Background to contemporary Greece I, eds Marion Sarafis, and Martin Eve, 35-51. London.

Mackridge, Peter. 2004. Diglossia and the separation of discourses in Greek culture. In Teoreticheskie problemy yazykoznaniya, ed. Sbornik Statey, 112-30. Filologicheskogo faku'lteta SanktPeterburgskogo gosudarstvennogo universiteta.

Mackridge, Peter. 2009. Language and national identity in Greece, 1766-1976. Oxford: Oxford University Press.

Mackridge, Peter. 2014. The Greek language since 1750. In Storia e storie e delle lingua greca, ed. Caterina Carpinato, and Olga Tribulato, 133-164. Venice: Edizioni Ca' Foscari.

Manolessou, Io, and Nikolaos Pantelidis. 2013. Velar fronting in Modern Greek Dialects. In Proceedings of the $5^{\text {th }}$ International Conference of Modern Greek Dialects and Linguistic Theory 2012, eds Mark Janse, Brian D. Joseph, Angela Ralli, and Metin Bagriacik, 272-286.

Newton, Brian. 1972. The generative interpretation of dialect: A study of Modern Greek phonology. Cambridge: Cambridge University Press.

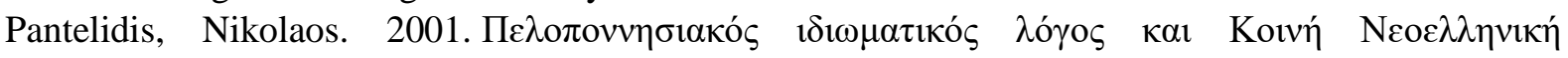
[Peloponnesian dialectal speech and Standard Greek]. Studies in Greek Linguistics 21: 550-561.

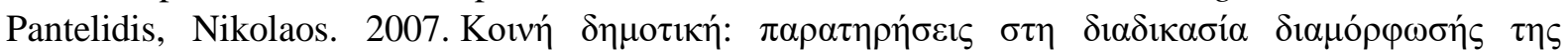
[Common demotic: Observations in the process of its creation]. Studies in Greek Linguistics 27: 337-347.

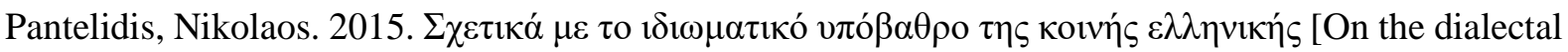

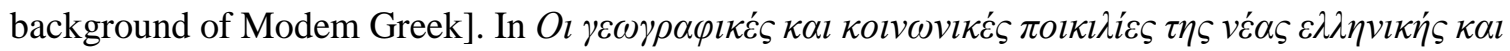

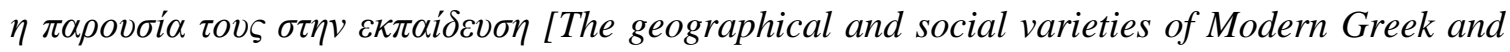
their presence in education], ed. John Androulakis, 41-50. Tyrnavos. 
Protopapas, Athanassios, Marina Tzakosta, Aimilios Chalamandaris, and Pirros Tsiakoulis. 2012. IPLR: An online resource for Greek word-level and sublexical information. Language Resources \& Evaluation 46 (3): 449-459.

Sfakianaki, Anna. 2002. The acoustic characteristics of Greek vowels produced by adults and children. In Selected papers on theoretical and applied linguistics from the 14th International Symposium, ed. Marianthi Makri-Tsilipakou, 383-394. Thessaloniki: Aristotle University.

Themistocleous, Charalambos. 2017. Modern Greek vowels and the nature of acoustic gradience. Phonetica 74: 157-172.

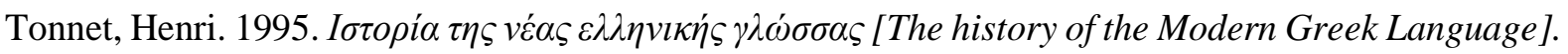
Athens.

Topintzi, Nina and Baltazani Mary. 2012. The acoustics of high vowel loss in a Northern Greek dialect and typological implications. In Consonant Clusters and Structural Complexity. Uncorrected proof. eds Phil Hoole, Lasse Bombien, Marianne Pouplier, Christine Mooshammer, and Barbara Kühnert. Interface Explorations series, Mouton de Gruyter.

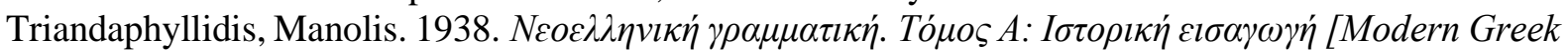
grammar. Volume A: Historical introduction]. Thessaloniki: Manolis Triandaphyllidis Foundation.

Trudgill, Peter. 2003. Modern Greek dialects: A preliminary classification. Journal of Greek Linguistics 4. 45-64.

Trudgill, Peter. 2009. Greek dialect vowel systems, vowel dispersion theory, and sociolinguistic typology. Journal of Greek Linguistics 9. 165-182.

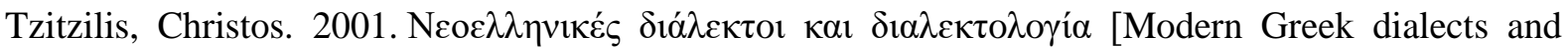

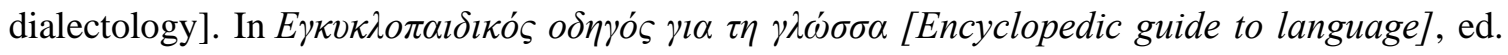
Anastasios-Foivos Christidis, 168-174. Thessaloniki: Centre for the Greek Language. 